\title{
Ecological effects of crude oil residues on the functional diversity of soil microorganisms in three weed rhizospheres
}

\author{
ZHANG Qian-ru', ${ }^{1,2}$ ZHOU Qi-xing ${ }^{1,3, *}$, REN Li-ping, ${ }^{1}$, ZHU Yong-guan ${ }^{4}$, SUN Shu-lan ${ }^{5}$ \\ (1. Key Laboratory of Terrestrial Ecological Process, Institute of Applied Ecology, Chinese Academy of Sciences, Shenyang 110016, China. E-mail: \\ Zhouqx@iae.ac.cn; 2. Graduate School of Chinese Academy of Sciences, Beijing 100039, China; 3. College of Environmental Science and \\ Engineering, Nankai University, Tianjin 300071, China; 4. Research Center for Eco-Environmental Sciences, Chinese Academy of Sciences, Beijing \\ 100085, China; 5. Kyushu University, Fukuoka 8128582, Japan)
}

\begin{abstract}
Ecological effects of crude oil residues on weed rhizospheres are still vague. The quantitative and diversity changes and metabolic responses of soil-bacterial communities in common dandelion (Taraxacum officinale), jerusalem artichoke (Silphium perfoliatum L.) and evening primrose (A calypha australis L.) rhizospheric soils were thus examined using the method of carbon source utilization. The results indicated that there were various toxic effects of crude oil residues on the growth and reproduction of soil bacteria, but the weed rhizospheres could mitigate the toxic effects. Total heterotrophic counting colony-forming units (CFUs) in the rhizospheric soils were significantly higher than those in the non-rhizospheric soils. The culturable soil-bacterial CFUs in the jerusalem artichoke (S. perfoliatum) rhizosphere polluted with $0.50 \mathrm{~kg} /$ pot of crude oil residues were almost twice as much as those with $0.25 \mathrm{~kg} /$ pot and without the addition of crude oil residues. The addition of crude oil residues increased the difference in substrate evenness, substrate richness, and substrate diversity between non-rhizospheric and rhizospheric soils of $T$. officinale and $A$. australis, but there was no significant $(p>0.05)$ difference in the Shannon's diversity index between non-rhizospheric and rhizospheric soils of $S$. perfoliatum. The rhizospheric response of weed species to crude oil residues suggested that $S$. perfoliatum may be a potential weed species for the effective plant-microorganism bioremediation of contaminated soils by crude oil residues.
\end{abstract}

Keywords: ecological effect; weed rhizosphere; crude oil residue; soil microorganism; functional diversity

\section{Introduction}

As one of the most important component parts of a soil ecosystem, soil microorganisms usually serve as one of the most sensitive indicators to characterize soil-biological properties and their changes (Kennedy and Smith, 1995; Finlay et al., 1997; Groffman and Bohlen, 1999), because of their instant responses to the changes in environmental conditions. Soil microorganisms, especially bacterial communities of the rhizosphere, can greatly regulate the functioning of soil ecosystems and their important processes such as nutrient transformation and organic matter decomposition, and significantly affect soil biodiversity, plant primary productivity and ecosystem health (Zhou, 2005). Nevertheless, there is much less knowledge about the roles of the composition of microbial communities in a polluted soil (Derry et al., 1999; Dobranic and Zak, 1999). Therefore, it is imperative to do research on the ecological effect on bacterial communities in a rhizosphere soil.

In the past decade there are increasing studies about soil-microbial communities in drastically different ecosystems, such as agricultural soils, forestland soils, grassland soils (Ovreas and Torsvik, 1998; Waldrop et al., 2000; Yao et al., 2000) and rhizospheric soils of various plant species (Grayston $e t$ al., 1998; Ibekwe and Kennedy, 1999; Miethling et al. , 2000; Marschner et al., 2001). However, surprisingly few studies have involved in ecological effects of crude oil pollution on microorganisms in rhizospheric soils despite the routine work of oil production has caused increasing environmental pollution. Due to the mismanagement, the phenomena of crude oil residues discharged into surrounding soils, roadsides and wastelands, in which weed plants grow thickly, are often observed in oil field regions. Some weed plants are ruined whereas other weed species still flourish even when soils are contaminated by a great deal of crude oil residues. Zhou and Song (2004) suggested that better understanding of relationships among specific plant systems and soil-microbial communities in crude-oil-contaminated soils would be useful to the development of effective bioremediation of crude-oilcontaminated soils based on the interaction between plants for phytoremediation and microorganisms in rhizosphere ecosystems. Then we address the question which is the keystone factor of the response of the weed rhizospheres to crude oil residues, the species of weed plants or the action of crude oil residues.

Rogers and Tate III (2001) suggested that the biolog assay (Biolog, Inc, Hayward, Callif) would be a more useful tool to indicate changes in a functional microbial community than the measurement of general soil-ecological processes because microbial assays, such as determination of biomass and enzyme activity, would be insensitive to the changes in microbial populations due to the redundancy of function within soil-microbial communities. The analysis of carbon source catabolisms with the biolog assay to give a 
community-level physiological profile (CLPP), has proven useful as a simple and rapid method to compare microbial communities from low-to moderate-nutrient habitats, such as soil, water, wastewater, contaminated sites, and activated sludge (Garland, 1997; Garland and Mills, 1991; Konopka et al., 1998). The biolog assay for community analysis involves in outgrowth of the whole ecosystem microbiota on multiple carbon substrates. The pattern of the substrate catabolism was expressed as an index of color development in each of the wells by the reduction of tetrazolium voilets, a redox indicator dye (Bochner, 1989) which changes from colorless to purple. Communities from similar or disparate environments may be differentiate by cluster and dimensioning techniques.

The objective of this research was to evaluate the responses of the rhizospheres of common dandelion (Taraxacum officinale), jerusalem artichoke (Silphium perfoliatum L.), and evening primrose (Acalypha australis L.), which are often growing in crude-oil contaminated soils, to crude oil residues using the method of carbon source utilization in order to develop a measurement of selecting plantmicroorganism bioremediation systems.

\section{Materials and method}

\subsection{Tested soil}

Topsoil $(0-20 \mathrm{~cm})$ samples of meadow burozem were collected from a relatively clean field in the Shilihe Station of Experimental Ecology, Chinese Academy of Sciences. The station is located in the continental temperature monsoon zone $\left(41^{\circ} 31^{\prime} \mathrm{N}\right.$, $123^{\circ} 24^{\prime} \mathrm{E}$ ), with a cold and snowy winter and a warm and humid summer. The annual average temperature is $7-8^{\circ} \mathrm{C}$, the annual precipitation averages $700 \mathrm{~mm}$, and the length of the annual frostless period is 147$164 \mathrm{~d}$. The chemical analysis using the regular analytical methods (He et al., 1998; Lu, 1999) indicated that soil $\mathrm{pH}$ was 6.65 , and the contents of organic carbon, total $\mathrm{N}$, and total $\mathrm{P}$ in the tested soil were $16.68,0.73$, and $0.66 \mathrm{~g} / \mathrm{kg}$, respectively.

\subsection{Pot-culture experiment}

The clean soil samples were mixed with crude oil residues from oil exploitation and abstraction in the Liaohe Oil Field at the two different levels of 0.25 and $0.50 \mathrm{~kg} /$ pot, corresponding to 5000 and $10000 \mathrm{mg}$ petroleum hydrocarbons $/ \mathrm{kg}$ soil, respectively. The untreated soil was regarded as the control (CK). All the treatments (Table 1) were replicated three times in order to decrease experimental errors. Then the oil soil was placed into ceramic pots $(\Phi=25 \mathrm{~cm}, H=15$ $\mathrm{cm}$ ), and the soil moisture content was adjusted to $80 \%$ of the field water-holding capacity. Three weed species $T$. officinale, S. perfoliatum L. and A. australis L. seedlings at the identical growth phase were transplanted to the pots. There were 6 seedlings in each pot. These seedlings in the pots were placed outside without a raining and sunlight defilade. Loss of water by evaporation from pots were daily recharged by tap water (no detection of petroleum hydrocarbons) to maintain $80 \%$ of the soil water-holding capacity. No fertilizer was added into the pot soils. Weed plants grown in these pots were harvested after their physical maturity when the frost occurred.

Table 1 Content of crude oil residues used in the microcosm experiment

\begin{tabular}{lcc}
\hline Latin name & $\begin{array}{l}\text { Content of crude oil } \\
\text { residues added to soil, } \\
\mathrm{kg} / \text { pot }\end{array}$ & $\begin{array}{l}\text { Concentration of } \\
\text { petroleum hydrocarbons, } \\
\mathrm{mg} / \mathrm{kg}\end{array}$ \\
\hline Taraxacum & 0 & 0 \\
officinale & 0.25 & 5000 \\
& 0.50 & 10000 \\
Silphium & 0 & 0 \\
perfoliatum L. & 0.25 & 5000 \\
& 0.50 & 10000 \\
Acalypha & 0 & 0 \\
australis L. & 0.25 & 5000 \\
& 0.50 & 10000 \\
\hline
\end{tabular}

\subsection{Sample collection and preparation}

After the mature plants were pulled out, rhizosphere soil samples were collected by shaking roots by hand to remove the soil adhering to roots. All visible small roots were carefully removed from rhizospheric soil samples. Prior to the storage at $4^{\circ} \mathrm{C}$ for the subsequent analysis of the BIOLOG profiles, the fresh samples were ground to pass a sieve of 2.0 $\mathrm{mm}$.

\subsection{BIOLOG assays}

The capability of soil-bacterial communities to utilize a variety of sole carbon sources was assessed using the BIOLOG GN plate (BIOLOG Inc., Hayward, CA) procedure adapted from Garland and Mills (1991). There were 96 wells in a BIOLOG GN plate, each containing 95 sole carbon sources such as carbohydrates, carboxylic acids, amino acids, amides polymers and miscellaneous compounds, and no addition of any sole carbon source (the control) in a separate well. Cell suspensions were prepared by extracting the rhizospheric soil samples with sterile $\mathrm{NaCl}(0.85 \%)$ solution, serially diluting, and adding a $150-\mu 1$ suspension of a $10^{-3}$ dilution to the BIOLOG plates using an 8-channel repeating pipette.

Plates were inoculated with 3 replicates of soil extract and incubated at $25^{\circ} \mathrm{C}$, and absorbance data were recorded at $590 \mathrm{~nm}$ at $0,24,48,72,96$ and $120 \mathrm{~h}$ using the BIOLOG reader 4.2 (Hayward, USA). The overall color development in the BIOLOG plates was expressed as average well color development 
(AWCD). The optical density (OD) readings were corrected for the control on each plate before data analysis. The $\mathrm{OD}$ values were processed by the control subtraction $\left(\mathrm{OD}_{0}\right)$, and the $\mathrm{AWCD}$ correction $\left(\mathrm{OD}_{0} / \mathrm{AWCD}=\mathrm{OD}_{\text {awe }} ; \mathrm{AWCD}=\right.$ (sum of $\mathrm{OD}_{0}$ values) 195). Variables with no color development in all observations (mean $\mathrm{OD}_{0} \leqslant 0$ ) were removed.

\subsection{Plate counting of bacterial populations}

The enumeration of viable bacterial colonies in the fresh rhizospheric soil samples was determined using the beef-extract-peptone agar (BEPA) media. About $10.0 \mathrm{~g}$ of fresh rhizosphere soil samples were weighed and placed to $90 \mathrm{ml}$ of $0.85 \%$ sterile $\mathrm{NaCl}$ solution, stirred for $5 \mathrm{~min}$ at room temperature, and serially diluted from $10^{-3}$ to $10^{-5}$. Agar plates were inoculated with $0.1 \mathrm{ml}$ of aliquots using the spread plate method and heterotrophic bacteria were incubated at $(30 \pm 1)^{\circ} \mathrm{C}$ for $2 \mathrm{~d}$.

\subsection{Data processing and statistic analyses}

Bacterial population counts and AWCD were analyzed using the two-way standard analysis of variance ( $t$-test) (ORIGIN 7.0, Microcal Software, Inc.). The AWCD of 6 substrate guilds was also calculated (Zak et al., 1994). The substrate utilization (SU) data (absorbance in each BIOLOG plate well, minus the control well) were subjected to the principle component analysis (PCA) using the covariance matrix. Two principle components (PCs) were extracted on the basis of a scatter plot. In order to decrease the influence of rarely utilized substrates, individual substrates which were not generally used (OD $<0.2$ for all samples) by any microorganism in rhizospheric soils were removed from the SU data before calculation of the substrate richness. All the SU data presented were based on $72 \mathrm{~h}$ incubation readings. The PCA analysis was conducted using the statistical analysis system ver. 8 (SAS Institute, Cary, $\mathrm{NC)}$.

\section{Results}

\subsection{Quantitative responses of soil-bacterial com-} munities to crude oil residues

Generally, there were inhibitory effects of crude oil residues from oil exploitation and abstraction on the growth and reproduction of most soil bacteria. On the contrary, some weed species can not only promote the growth and reproduction of soil bacteria, but also mitigate toxic effects of crude oil residues on soil-bacterial communities to a certain extent. As shown in Fig.1, colony-forming units (CFUs) in the rhizospheric soils of $T$. officinal and $A$. australis $\mathrm{L}$. were $124 \%$ and $147 \%$ higher than those in the non-rhizospheric soils without the addition of crude oil residues, respectively. However, total heterotrophic CFU in the rhizospheric soils was also significantly higher than that in the bulk soils when plants were exposed to crude oil residues probably due to the detoxification of weed rhizospheres. The rhizosphere mitigation of the toxicity of crude oil residues may be dependent on types of weed species and the concentration of crude oil added to soil. CFU of soil-bacterial population in $S$. perfoliatum L. rhizospheric soils polluted by $0.50 \mathrm{~kg} /$ pot of crude oil residues was almost twice as much as that by 0.25 $\mathrm{kg} /$ pot and that without the addition of crude oil residues. It has been demonstrated that the bacterial population in $S$. perfoliatum L. rhizosphere soil developed specific mechanisms resisting to crude oil residues. Moreover, the results showed that there were two opposite trends in the response of soil bacteria in three weed rhizospheres to the stress of different contents of crude oil residues added to soil. When the content of crude oil residues added to soil was 0.25 $\mathrm{kg} / \mathrm{pot}$, the total amount of culturable soil-bacteria in rhizospheres was in the sequence $T$. officinale $>S$. perfoliatum $\mathrm{L}$. $>A$. australis $\mathrm{L}$. The total amount of culturable soil-bacteria in $T$. officinale rhizospheric soils increased by $510 \%$ compared with that of the bulk soil particularly. On the other hand, the sequence of CFU was $T$. officinale $<S$. perfoliatum L. $<A$. australis $\mathrm{L}$. when the content of crude oil residues added to soil was up to $0.50 \mathrm{~kg} /$ pot. Particularly, CFU in A. australis L. rhizospheric soil was $278 \%$ of that of the bulk soil.

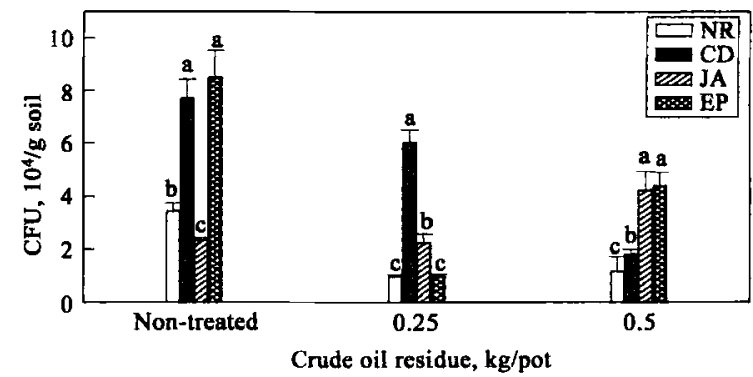

Fig. 1 Changes of total heterotrophic CFU in three weed rhizospheric soils under the stress of crude oil residues compared with the control NR. the bulk soil (the control); CD: $T$. officinale; JA: S. pe foliatum L.; EP: A. australis L.; error bars represent standard deviations; values with a different letter are significantly different from each other at the same content of crude oil residues $(p<0.05)$

\subsection{Diversity responses of soil-bacterial commu- nities to crude oil residues}

According to Zak et al. (1994), substrate utilization (SU) data, including substrate evenness (the average optical density of all wells in a plate), substrate richness (the numbers of utilizable substrates) and substrate diversity (using the Shannon's diversity index), can reflect diversity responses of bacterial communities. The results indicated that there were significant differences in substrate evenness, substrate richness, and substrate diversity between bulk and rhizosphere without the addition of crude oil residues. In particular, substrate 
richness in the three weed rhizospheric soils without the addition of crude oil residues was markedly higher than that in bulk soil without the addition of crude oil residues. However, the addition of crude oil residues resulted in an increase in the difference of substrate evenness, substrate richness, and substrate diversity between bulk and the rhizospheric soils of $T$. officinale and $A$. australis $\mathrm{L}$. The values of the three indices of bulk soil were increased by the addition of crude oil residues. On the contrary, those in the $T$. officinale and $A$. australis $\mathrm{L}$. rhizosphere soil decreased (Table 2). The diversity responses of bacterial communities in polluted rhizosphere soils of $S$. perfoliatum $\mathrm{L}$. were different from that of the two weed rhizospheric soils mentioned above. There was no significant $(p>0.05)$ difference of diversity with/without the addition of crude oil residues. In other words, the rhizosphere action of S. perfoliatumcan L. mitigate toxic effects of crude oil residues on the diversity of soil-bacterial communities.

Table 2 Effects of crude oil residues on founctional diversity of weed rhizosphere microcosms as evaluated by indices for 95 sole carbon source substrates (BIOLOG GN2 plates)"

\begin{tabular}{lccc}
\hline \multirow{2}{*}{ Indices } & \multicolumn{4}{c}{ Content of crude oil residues, $\mathrm{kg} / \mathrm{pot}$} \\
\cline { 2 - 4 } & 0 & 0.25 & 0.50 \\
\hline Substrate evenness & & \\
Bulk & $0.06 \pm 0.02 \mathrm{a}(\mathrm{A})$ & $0.59 \pm 0.03 \mathrm{a}(\mathrm{B})$ & $0.85 \pm 0.04 \mathrm{a}(\mathrm{C})$ \\
$\mathrm{CD}$ & $1.21 \pm 0.07 \mathrm{~b}(\mathrm{~A})$ & $0.77 \pm 0.05 \mathrm{~b}(\mathrm{~B})$ & $0.81 \pm 0.06 \mathrm{a}(\mathrm{C})$ \\
$\mathrm{JA}$ & $0.71 \pm 0.02 \mathrm{c}(\mathrm{A})$ & $0.77 \pm 0.11 \mathrm{~b}(\mathrm{~A})$ & $0.78 \pm 0.05 \mathrm{a}(\mathrm{A})$ \\
EP & $1.12 \pm 0.05 \mathrm{~b}(\mathrm{~A})$ & $0.93 \pm 0.03 \mathrm{c}(\mathrm{B})$ & $0.72 \pm 0.03 \mathrm{a}(\mathrm{C})$
\end{tabular}

Substrate richness

$\begin{array}{llll}\text { Bulk } & 11 \pm 2 a(A) & 61 \pm 7 a(B) & 86 \pm 4 a(C) \\ \text { CD } & 94 \pm 4 b(A) & 61 \pm 7 a(B) & 84 \pm 7 a(A) \\ \text { JA } & 76 \pm 2 c(A) & 80 \pm 3 b(A) & 79 \pm 3 a(A) \\ \text { EP } & 90 \pm 3 b(A) & 88 \pm 3 b(A) & 71 \pm 4 a(B)\end{array}$

Shannon's diversity index

Bulk $\quad 3.17 \pm 0.10 \mathrm{a}$ (A) $4.03 \pm 0.07 \mathrm{a}$ (B) $4.17 \pm 0.06 \mathrm{a}$ (B)

$\mathrm{CD} \quad 4.26 \pm 0.05 \mathrm{~b}$ (A) $3.93 \pm 0.07 \mathrm{a}$ (B) $4.20 \pm 0.06 \mathrm{a}(\mathrm{A})$

JA $4.18 \pm 0.03 \mathrm{~b}$ (A) $4.17 \pm 0.06 \mathrm{a}$ (A) $4.20 \pm 0.04 \mathrm{a}$ (A)

EP $\quad 4.25 \pm 0.05 \mathrm{~b}$ (A) $4.24 \pm 0.08 \mathrm{a}(\mathrm{A}) 4.13 \pm 0.04 \mathrm{a}(\mathrm{A})$

Notes: " Means followed by different letters differ at $p<0.05$ ( $t$-test); letters beside means refer to the difference of the bulk and three weed rhizospheres at the same content of crude oil residues and capital letters means refer to the difference at the different content of crude oil residues; "when substrates with absorbance $>0.2$, metabolizing was considered

\subsection{Metabolic responses of soil-bacterial com-} munities to crude oil residues

The metabolic profiles of soil-bacterial com munities could be expressed as a sigmoidal curve on the basis of the relationship between color development of the BIOLOG wells and the incubation time. AWCD was very low within the first $24 \mathrm{~h}$, rapidly increased from $24 \mathrm{~h}$ to $72 \mathrm{~h}$, and slowly increased after $72 \mathrm{~h}$ (Fig.2). Such values were obtained for all soil-bacterial community samples with/without the addition of crude oil residues. SU data to reflect metabolic responses of soil-bacterial communities were also subdivided into 6 guilds according to the chemical nature of 95 sole carbon sources and the average absorbance within each guild was analyzed in the same manner as for all substrates (Table 3). Guild-specific differences among various weed rhizospheres may be related to the ability of the bacterial community to degrade specific categories of carbon sources which were almost representative of plant root exudates.

The AWCD of the bacterial community in bulk soil without addition of crude oil residues showed the lower value than AWCD for three weed rhizospheric soils throughout the incubation time. (Fig.2a). This illustrated that bacteria in weed rhizospheres would consume much more carbon sources as energy than those in the bulk soil to support their living activities, but the two main substrate-rich guilds differed from one another (Table 3).

In $T$. officinale and $A$. australis $\mathrm{L}$. rhizospheric soils, the two main substrate-rich guilds were carbohydrates and amino acids. Amino acids and amides became the two main substrate-rich guilds in S. perfoliatum L. rhizosphere. It indicated that types of plant species play a determinate role in the metabolic

Table 3 AWCD in the 6 guilds of carbon sources in the BIOLOG GN plate by weed rhizosphere microcosms with/without the pollution of crude oil residues

\begin{tabular}{|c|c|c|c|c|c|}
\hline \multirow{2}{*}{ Carbon source } & \multirow{2}{*}{$\begin{array}{l}\text { Content of crude } \\
\text { oil residues, } \mathrm{kg} / \text { pot }\end{array}$} & \multicolumn{4}{|c|}{ Weed species } \\
\hline & & Bulk & $\mathrm{CD}$ & JA & EP \\
\hline \multirow[t]{3}{*}{ Carbohydrate } & 0 & 0.139 & 1.600 & 0.582 & 1.560 \\
\hline & 0.25 & 0.753 & 1.436 & 0.783 & 1.277 \\
\hline & 0.50 & 1.008 & 0.792 & 0.783 & 0.722 \\
\hline \multirow[t]{3}{*}{ Carboxylic acid } & 0 & 0 & 0.999 & 0.786 & 0.842 \\
\hline & 0.25 & 0.677 & 0.615 & 0.866 & 0.851 \\
\hline & 0.50 & 0.649 & 0.862 & 0.939 & 0.851 \\
\hline \multirow[t]{3}{*}{ Amino acid } & 0 & 0.019 & 1.232 & 1.008 & 1.141 \\
\hline & 0.25 & 0.519 & 0.377 & 0.960 & 0.755 \\
\hline & 0.50 & 0.975 & 1.036 & 0.850 & 0.78 \\
\hline \multirow[t]{3}{*}{ Amide } & 0 & 0.018 & 1.208 & 0.905 & 0.885 \\
\hline & 0.25 & 0.386 & 0.107 & 0.596 & 0.587 \\
\hline & 0.50 & 0.288 & 1.040 & 0.686 & 0.620 \\
\hline \multirow[t]{3}{*}{ Polymer } & 0 & 0.012 & 1.135 & 0.558 & 1.062 \\
\hline & 0.25 & 0.440 & 0.151 & 0.596 & 1.268 \\
\hline & 0.50 & 1.397 & 0.688 & 0.594 & 0.626 \\
\hline \multirow[t]{3}{*}{ Miscellaneous } & 0 & 0.065 & 0.845 & 0.466 & 0.809 \\
\hline & 0.25 & 0.300 & 0.628 & 0.407 & 0.620 \\
\hline & 0.50 & 0.665 & 0.421 & 0.487 & 0.488 \\
\hline \multirow[t]{3}{*}{ AWCD } & 0 & 0.055 & 1.214 & 0.714 & 1.124 \\
\hline & 0.25 & 0.585 & 0.768 & 0.766 & 0.933 \\
\hline & 0.50 & 0.854 & 0.805 & 0.777 & 0.721 \\
\hline
\end{tabular}



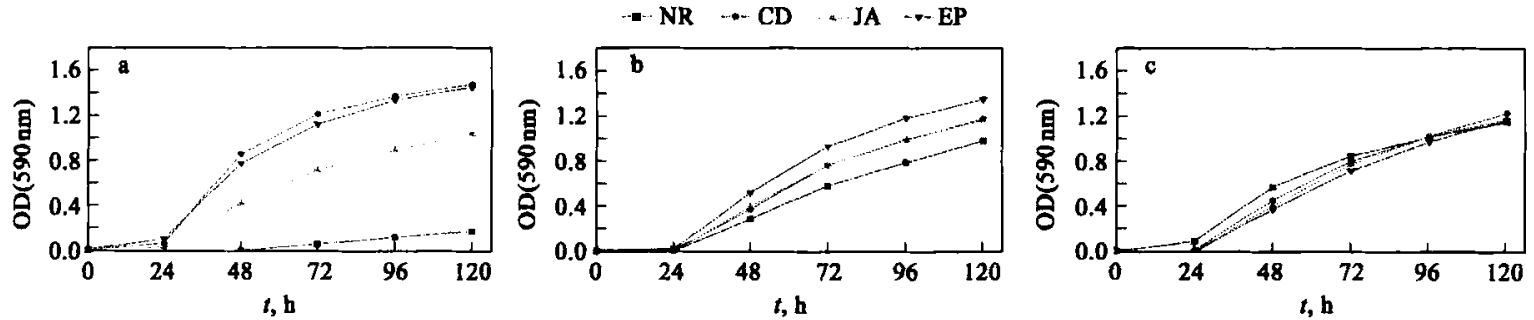

Fig.2 AWCD profiles (OD (590 nm)) of 95 sole carbon source substrates from the bulk and weed rhizospheric soils without the addition (a) and with the addition of crude oil residues with different contents of $0.25 \mathrm{~kg} /$ pot (b) and $0.50 \mathrm{~kg} /$ pot (c)

profiles of rhizosphere bacterial community without the addition of extra energy source. Due to addition of crude oil residues to soil, the AWCD of bacterial community in bulk and rhizosphere soil was gradually tending to the same value (Figs. $2 \mathrm{~b}$ and $2 \mathrm{c}$ ). To explain more appropriately the results from a biochemical point of view, the two main substrate-rich guilds were determined on the basis of the bacterial utilization of carbon sources occurred potentially in the rhizospheres. Under the pollution of $0.25 \mathrm{~kg} / \mathrm{pot}$, the two main substrate-rich guilds were changed into carbohydrates and carboxylic acids in bulk soil, carbohydrates and miscellaneous in $T$. officinale rhizosphere soil, amino acids and carboxylic acids in S. perfoliatum L. rhizosphere soil, and carbohydrates and polymers in $A$. australis $\mathrm{L}$. rhizosphere soil. When the content of crude oil residues added to soil was $0.50 \mathrm{~kg} / \mathrm{pot}$, they were further changed into polymers and carbohydrates in bulk soil, and amides and amino acids in $T$. officinale rhizosphere soil, carboxylic acids and amino acids in $S$. perfoliatum L. rhizosphere soil, and carboxylic acids and amino acids in $A$. australis L. rhizosphere soil. The results in Table 3 indicated that responses of rhizosphere communities to crude oil residues were characterized by transformation of carbon sources, in particular, carbohydrates and amino acids were the two important sensitive carbon sources.

\section{Discussion}

To further interpret the complex patterns produced from the substrate utilization analysis, the multivariate statistical tool of PCA was used to reduce the variation into its most significant components. This analysis used the $72 \mathrm{~h}$ data because this incubation time resulted in the greatest discrimination among the treatments. The data presented in Fig.3 showed that the functional ability of heterotrophic soil-bacterial communities was altered by crude oil residues. All SU data in bulk and rhizospheric soils exhibited distinctly different profiles based on PC1 and PC2 due to addition of crude oil residues. There were three main groupings: (1) the bulk soil; (2) $T$. officinale and $A$. australis L. rhizosphere soil; and (3) $S$. perfoliatum L. rhizosphere soil. The variance amounted to $80.1 \%$ for $\mathrm{PCl}$ and $11.4 \%$ for $\mathrm{PC} 2$ (Fig. 3a). For the soil treated with $0.25 \mathrm{~kg} /$ pot of crude oil residues (Fig.3b), the scores for $T$. officinale rhizosphere soil were separated along PCl $(51.7 \%)$ from those of the bulk soil, $S$. perfoliatum $\mathrm{L}$. and $A$. australis $\mathrm{L}$. rhizosphere soils all on the left of $\mathrm{PC}$. Whereas, SU patterns of three weed rhizosphere soil combined a cluster diverged from the bulk soil along PC1 $(47 \%)$ for $0.50 \mathrm{~kg} /$ pot of crude oil residues added to soil (Fig.3c). The excursion was significant on PC scores due to addition of crude oil residues. PC scores of $T$. officinale and $A$. australis $\mathrm{L}$. rhziosphere soil shifted from the positive axis of $\mathrm{PC} 1$ to the negative axis, while scores of the bulk soil shifted along $\mathrm{PCl}$ from negative to positive. The PC1 and PC2 scores of $S$. perfoliatum $\mathrm{L}$. rhizosphere soil under the stress of $0.50 \mathrm{~kg} /$ pot crude oil residues were similar to those without crude oil residues.

Due to the detoxification of weed rhziospheres, the CFUs in rhizospheric soils were higher than those in bulk soil in presence of crude oil residues. Especially, the rhizosphere effect of $S$. perfoliatum L. resulted in the significant increment of CFU at the high level of crude oil residues compared with the bulk soil. Moreover, bacteria in rhizosphere soil developed specific resistance mechanisms to adapt to the contaminated habitats. Since some special bacteria can utilize petroleum hydrocarbons as energy, it is certain to promote growth and activity of these bacteria. Hence considering the substrates utilized by bacteria, petroleum hydrocarbons should not be simply regarded as a toxicant. However, the results of CFU only reflected quantitative responses of cultural dominant and the fastest growing bacterial population and did not represent the overall diversity and metabolic responses of bacterial communities in the rhizospheres to crude oil residues.

Griffiths et al. (1999) evidenced that changes in the substrate supply altered the structure and functioning of microbial populations in a rhizosphere and suggested that the flux of substrates is a governing factor for the composition of microbial communities. Carbon compounds in root exudates vary not only with the plant species but also with the concentration of pollutants. The diversity response of soil-bacterial communities in a rhizosphere to crude oil residues demonstrated that the different types of weed species could directly affect the symbiosis relationships 

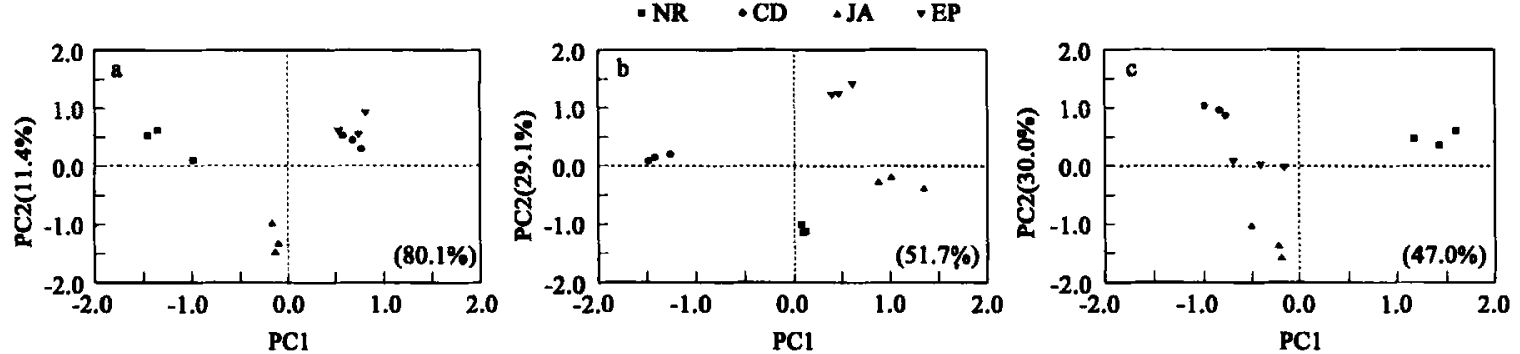

Fig.3 Scatter plots of principal components (PCs) 1 and 2 performed on BIOLOG GN fingerprints of soil extracts from the bulk and weed rhizospheric soils in no addition (a) and addition with different contents of $0.25 \mathrm{~kg} / \mathrm{pot}$ (b) and $0.5 \mathrm{~kg} / \mathrm{pot}$ (c) crude oil residues

between weed plants and rhizosphere microorganisms. Different communities might have different responses to substrates flux in terms of growth and activity so that the diversity of soil-bacterial communities can be changed through themselves and their reaction with the plants. Even though there were some factors to affect substrate-rich guilds, our results suggested that the concentration of crude oil residues might be an important factor in the flux of substrate. The guild of carbohydrates provided main carbon sources at the low level of crude oil residues, and at the high level of crude oil residues it was the guild of amino acids. This phenomenon might be due to the complexity of petroleum hydrocarbons and the selectivity of rhizosphere microorganisms, thus weakening the weed rhizosphere effect.

In presence of crude oil residues, the two main substrate-rich guilds still were amino acids and carboxylic acids in $S$. perfoliatum L. rhizospheres. It implied that the rhizosphere action of $S$. perfoliatum $\mathrm{L}$. could provide the stable rhizosphere environment to rhizobacteria through some chemical reactions to utilize petroleum hydrocarbons more efficiently at a certain extent. Therefore, we suggest that $S$. perfoliatum L. can be considered as a potential weed species for the joint plant-microorganism bioremediation of contaminated soils by crude oil residues. In conclusion, studies focused on the ecological effects of soil-bacterial communities in weed rhizospheres to crude oil residues not only can lead to a better understanding of rhizobacterial behavior in contaminated environment but can also help in finding right strategies to enhance the adaptation of plant-microorganism bioremediation to an ecological niche.

Acknowledgements: The authors gratefully thank Dr. S. H. Wei for his having managed the pot experiment, and thank Dr. W. D. Kong and Dr. Z. G. Fang for their technical assistance in the BIOLOG assays.

\section{References:}

Bochner B T, 1989. Breathprints at the microbial level[J]. American Society for Microbiology News, 55: 536-539.

Derry A M, Staddon W J, Kevan P G et al., 1999. Functional diversity and community structure of micro-organisms in three arctic soils as determined by sole-carbon-source-utilization[J]. Biodivers Conserv, 8: 205-221.
Dobranic J K, Zak J C, 1999. A microtiter plate procedure for evaluating fungal functional diversity[J]. Mycologia, 91: 756765.

Finlay B J, Maberly S C, Cooper J I, 1997. Microbial diversity and ecological function[J]. Oikos, 80: 209-213.

Garland J L, 1997. Analysis and interpretation of community-level physiological profiles in microbial ecology[J]. FEMS Microbiol Ecol, 24: 289-300.

Garland J L, Mills A L, 1991. Classification and characterization of heterotrophic microbial communities on the basis of patterns of community-level sole-carbon-source utilization[J]. Applied. Environ Microbiol, 57: 2351 - 2359.

Grayston S J, Wang S, Campbell C Det al., 1998. Selective influence of plant species on microbial diversity in the rhizosphere[J]. Soil Biol Biochem, 30: 369--378.

Griffiths B S, Ritz K, Ebblewhite N et al., 1999. Soil microbial community structure effects of substrate loading rates[J]. Soil Biol Biochem, 31: 145-153.

Groffman P M, Bohlen P J, 1999. Soil and sediment biodiversitycross-system comparisons and large-scale effects[J]. BioScience, 49:130-148.

He Z L, Zhou Q X, Xie Z M, 1998. Soil-chemical equilibriums of polluted and beneficial elements[M]. Beijing: China Environmental Science Press.

Ibekwe A M, Kennedy A C, 1999. Fatty acid methyl ester (FAME) profiles as a tool to investigate community structure of two agricultural soils[J]. Plant Soil, 206: 151-161.

Kennedy A C, Smith K L, 1995. Soil microbial diversity and the sustainability of agrochultural soils[J]. Plants Soil, 170: 75-86.

Konopka A, Oliver L, Turco R F, 1998. The use of carbon substrate utilization patterns in environmental and ecological microbiology [J]. Microb Ecol, 35: 103-115.

Lu R K, 1999. Analysis methods in soil agrochemical[M]. Beijing: Agricultural Science and Technology Press.

Marschner P, Yang C H, Lieberei R et al., 2001. Soil and plant specific effects on bacterial community composition in the plant rhizosphere[J]. Soil Biol Biochem, 33: 1437-1445.

Miethling R, Wieland G, Backhaus $\mathrm{H}$ et al, 2000. Variation of microbial rhizosphere communities in response to crop species, soil origin, and inoculation with Sinorhizobium meliloti L33 [J]. Microb Ecol, 41: 43-56.

Ovreas L, Torsvik V, 1998. Microbial diversity and community structure in two different agricultural soil communities [J]. Microb Ecol, 36: 303-315.

Rogers B F, Tate III R L, 2001. Temporal analysis of the soil microbial community along a toposequence in Pineland soils[J]. Soil Bio Biochem, 33: 1389-1401.

Waldrop M P, Balser T C, Firestone M K, 2000. Linking microbial community composition to function in a tropical soil[J]. Soil Biol Biochem, 32: 1837-1846.

Yao $\mathrm{H}$, He Z, Wilson M J et al., 2000. Microbial biomass and community structure in a sequence of soils with increasing fertility and changing land use[J]. Microb Ecol, 40: 223-237.

Zak J C, Willig M R, Moorhead D L et al., 1994. Functional diversity of microbial communities: a quantitative approach[J]. Soil Biol Biochem, 26: 1101-1108.

Zhou Q X, Song Y F, 2004. Principles and methods of contaminated soil remediation[M]. Beijing: Science Press.

Zhou Q X, 2005. Health soil science: soil health quality and safety of agricultural products[M]. Beijing: Science Press.

(Received for review November 28, 2005. Accepted March 5, 2006) 